For citation: Utama, Ch. \& Melianna, R. (2020). The Role of Monetary Policy in Comparative Advantage and Trade Balance of Capital Intensive Industry in Indonesia. Ekonomika Regiona [Economy of Region], 16(1), 298-309

https://doi.org/10.17059/2020-1-22

UDC: 336.02

JEL: E52, E4, F4, N7

a) Universitas Katolik Parahyangan — Indonesia (Kota Bandung, Indonesia; e-mail: chandradst@unpar.ac.id)

b) Lembaga Ilmu Pengetahuan Indonesia (Jakarta, Indonesia)

\title{
THE ROLE OF MONETARY POLICY IN COMPARATIVE ADVANTAGE AND TRADE BALANCE OF CAPITAL-INTENSIVE INDUSTRY IN INDONESIA
}

This paper examines the influence of monetary policy on comparative advantage and trade balance of capital-intensive industries (technology-intensive industry and human capital-intensive industry). Ever since Indonesia implemented the Inflation Targeting Framework (ITF) in 2005, the average interest rates have been gradually declining, making capital more affordable. The Heckscher-Ohlin-Samuelson (HOS) model states that lower interest rates will improve comparative advantage and trade balance of capital-intensive industry. In our research we used annual export and import dat for the period from 2000 to 2017, drawing on the threedigit Standard International Trade Classification (SITC) revision 2 from United Nations Commodity Trade Statistics Database (UN-COMTRADE). The study combines Revealed Symmetric Comparative Advantage (RSCA) and Trade Balance Index (TBI), used for analysing Product Mapping. Additionally, we applied the Difference in Differences $(D D)$ model to measure the real impact of the ITF on capital-intensive industries choosing unskilled labour-intensive products as a control group. For analysing the effect of the ITF on probability of positive changes of comparative advantage and trade balance we used the Logit model. Based on product mappings, we cannot conclude that the situation for capital-intensive products is better in 2014 than in 2000, pre-ITF. However, the DD and the Logit model show that the ITF positively influences comparative advantage and trade balance of capital-intensive products and significantly impacts trade balance of unskilled labour-intensive products. The study concludes that the ITF have positive impact on comparative advantage and trade balance of capital-intensive industry in Indonesia.

Keywords: capital-intensive industry, monetary policy, interest rates, inflation targeting, international trade, export, comparative advantage, trade balance, Indonesia, difference in differences

\section{Introduction}

Central bank of Indonesia (Bank Indonesia or BI) introduced The Inflation Targeting Framework (ITF) in 2001 and officially implemented it in July 2005. Based on Taylor rule [1, 2], BI and central banks of various countries confirm that shortterm interest rates works better than the monetary aggregate for their operational target to manage inflation. BI gradually decreases interest rates in order to reduce inflation and expected inflation in Indonesia. The study done by Utama et al. [3] using provincial data of Indonesia shows the role of interest rates in maintaining inflation in Indonesia.

Central bank also influences currency exchange rates by manipulating interest rates. Using the data of 14 industrialized countries, MacDonald \& Nagayasu [4] found evidence of statistically significant long-run relationships between real ex-

${ }^{1}$ ( ) Utama Ch., Meilianna R. Text. 2020. change rates and real interest rate differentials among countries. Lower interest rates push domestic capital abroad and cause the exchange rate to depreciate, at the same time increasing net export and term of trade. The increase in export causes growth of aggregate demand that has a positive effect on inflation. Additionally, lower interest rates increase aggregate supply since it is lowering the cost of capital. If the effect of reducing interest rates is higher for aggregate supply than aggregate demand, the inflation will decline.

Figure 1 shows the monthly movements of interest rates before and during the implementation of the ITF since July 2005. The deposit and investment loan interest rates move along the decline of the central bank or policy interest rates. The declining trend of interest rates of investment loans after the implementation of the ITF should be more advantageous for the capital-intensive industry than for labour-intensive industry, since the cost of capital becomes lower relative to wages. Furthermore, we define capital-intensive 


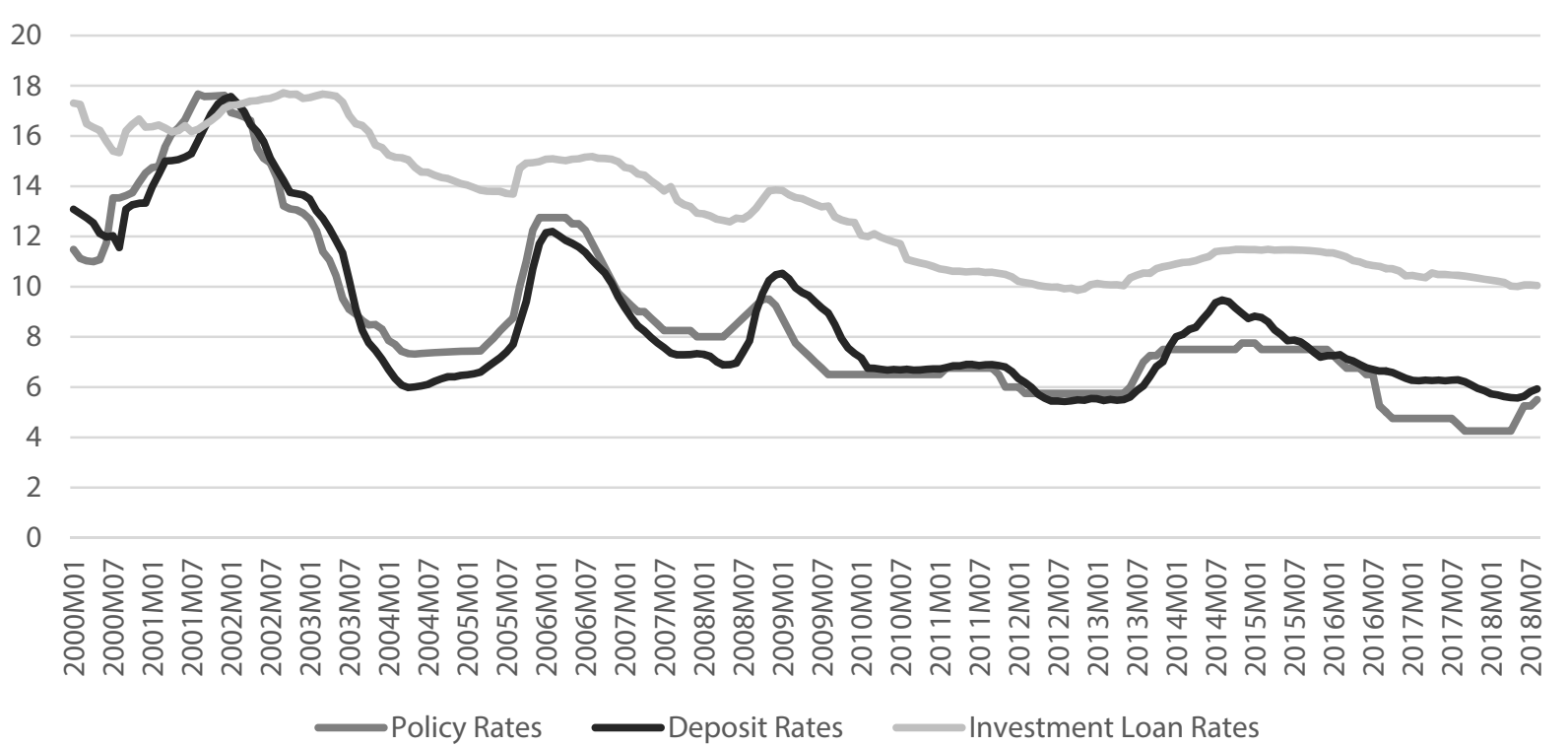

Sources: Bank Indonesia

Fig. 1. Interest rates of investment loans, deposit interest rates, and policy interest rates (\%)

industry as the industry that in production dominantly uses technology and skilled labour. The labour-intensive industry is defined as the industry that dominantly uses unskilled labour in production. The list of product classification is shown in Table 1.

The Masterplan for Acceleration and Expansion of Indonesia's Economic Development (MP3EI) states that the manufacturing sector is crucial for Indonesia, as its development would allow the country to be in the top 10 economies by 2025 . Indonesia must upgrade the value added, efficient distribution networks, and utilize natural and human resources of manufacturing sector [5]. The effective development of the manufacturing is necessary for achieving long-term prosperity through significant progress in technology, quality, innovation, and labour productivity. The characteristic industry that must be upgraded should be the industry that dominantly and intensively uses technology and skilled labour in production.

This study explores the role of monetary policy supporting the development of the manufacturing sector, especially capital-intensive industries by measuring the role of interest rates $^{1}$ in the ITF implementation aimed at improving comparative advantage and trade balance of technology-intensive and skilled labour-intensive sectors. Based on the model of Heckscher-Ohlin Samuelson (HOS), country exports goods that use the relatively abundant factors of production [6, p. 143]. Interest rate policy can stimulate pro-

\footnotetext{
${ }^{1}$ We used real interest rate (nominal interest rate - inflation rate) in this study since interest rate is operational target to find targeted inflation rate.
}

duction level of output $[7,8]$ through the increase of comparative advantage [4]. The use of capital rises when interest rate decreases [9]. Jorgenson [9] claims that interest rates increase investment through the reduction of the cost of capital. The growth of comparative advantage increases export consequently increasing output of economy. The study of Grossman \& Helpman [10] demonstrates the role of comparative advantage to long run economic growth.

We need to use more than one approach to reveal the influence of the ITF on comparative advantage and trade balance. The global financial crisis of 2008-2010 may hinder the results, making the influences undetected if we only apply one approach. HOS prediction of international trade may be confused since there are negative effects of the crisis on international trade globally. The first approach analyses the direct influence of the ITF on capital-intensive products by looking at the trade balance index and comparative advantage index partially. The second approach examines the influence of the ITF by looking at the relative influence of the ITF by comparing the group of capital-intensive products with non-capital intensive products. The comparisons in the first and second approaches are made taking one point (year) before the ITF and one point after the ITF. The third approach, Logit model, analyses the change of the role of interest rates on competitiveness and trade balance before the ITF and during the ITF. This approach uses panel data for the period from 2000 to 2017. This study investigates whether the application the ITF improve comparative advantage and trade balance for capital-intensive products in Indonesia. 


\section{Theoretical Bases}

Monetary policy is used to stabilize price and output level with the help of short-term interest rates as the operational target. The relationship between interest rates and inflation can be explained though Taylor rule [1, 2]. Taylor rule demonstrates how much the central bank may need to change the current interest rates when inflation, output level, and other economic conditions change. The Taylor rule can be stated as:

$$
i_{t}=\pi_{t}+r_{t}^{*}+a_{\pi}\left(\pi_{t}-\pi_{t}^{*}\right)+a_{y}\left(y_{t}-\bar{y}_{t}\right),
$$

where $i_{t}$ is the short-term nominal interest rate, $\pi_{t}$ is inflation rate, $\pi^{*}$ is targeted inflation rate, $r_{t}^{*}$ is assumed as real interest rate equilibrium, $y_{t}$ is the real gross domestic product (GDP), $\bar{y}_{t}$ is potential output. Figure 1 shows that the nominal interest rates are gradually decreasing in the era of the ITF. The following Heckscher-Ohlin-Samuelson (HOS) model explains the effect of lower interest rates on comparative advantage and trade balance.

Bowen et al. [6, p. 114] present the factor abundance model or HOS. The model is simplified by assuming there are 2 products, $q_{1}$ and $q_{2}$, and 2 factor production, capital $K$ and labour $L$, in economy. The production function of industry $j$ is stated as:

$$
q_{j}=F\left(K_{j}, L_{j}\right), j=1,2 .
$$

The equation (2) satisfies neoclassical production function. The industry j profit maximization problem can be stated as:

$$
\begin{gathered}
\Pi_{j}\left(p_{j}, w_{j}, r_{j}\right)=\max _{L_{j}, K_{j}}\left(p_{j} q_{j}-w_{j} L_{j}-r_{j} K_{j}\right) \\
\text { subject to } q_{j}=L_{j} f_{j}\left(k_{j}\right),
\end{gathered}
$$

where $p$ is price of output, $w$ is wage of labour, $r$ is rental or interest rate, and $k$ is a capital-labour ratio. Assuming the outputs $q_{1}$ and $q_{2}$ are produced in equilibrium, the solution (3) yield condition that $K$ and $L$ paid in their marginal product:

$$
w_{j}=p_{j}\left(f_{j}-k_{j} f_{j}^{\prime}\right) \text { and } r_{j}=p_{j} f_{j}^{\prime} \text {, }
$$

Furthermore, the optimal factor allocation can be written as:

$$
\begin{gathered}
p_{1}\left(f_{1}-k_{1} f_{1}^{\prime}\right)=w_{j}=p_{2}\left(f_{2}-k_{2} f_{2}^{\prime}\right) \\
\text { and } p_{1} f_{1}^{\prime}=r=p_{2} f_{2}^{\prime} .
\end{gathered}
$$

Equation (5) states the allocations of capital and labour are the same as marginal product and equal for each industry. The economy's wagerental ratio $(\omega)$ is obtained by dividing $w$ by $r$ in (4):

$$
\omega\left(k_{j}\right)=\frac{f_{j}\left(k_{j}\right)}{f_{j}^{\prime}\left(k_{j}\right)}-k_{j}, j=1,2,
$$

where $\frac{d \omega}{d k_{j}}=\frac{f_{j} f_{j}^{\prime \prime}}{\left(f_{j}^{\prime}\right)^{2}}>0$ and $\frac{d k_{j}}{d \omega}=-\frac{\left(f_{j}^{\prime}\right)^{2}}{f_{j} f_{j}^{\prime \prime}}>0$.

The positive relation between $k_{j}$ and $\omega$ implies that the decline in the rental makes producers in each industry to reduce labour and rise capital (or fix labour and rise capital). Furthermore, if industry 1 is a labour-intensive industry and industry 2 is a capital-intensive industry, then the industry 2 will benefit more than industry 1 when rental is permanently declined, since industry 2 is more likely to increase capital than industry 1 . The benefit of interest rates reduction depends on the proportion of capital in production.

The Heckscher-Ohlin (HO) model states that a country has comparative advantage and exports the goods that are produced using relatively abundant factor intensively. The home country is defined to be abundant in capital relative to labour if:

$$
k \equiv \frac{K}{L}>\frac{K^{*}}{L^{*}} \equiv k^{*} \text { or } \omega_{a}>\omega_{a}^{*},
$$

where an asterisk denotes the rest of the world. Bowen [6, p. 145] argue that the definition of the factor abundance involves relative comparison, relative size of $K / L$ and $K^{*} / L^{*}$, or $\omega_{a}$ and $\omega_{a}^{*}$, not numerical value of each ratio. Furthermore, based on equations (6) and (7), lower interest rates will increase comparative advantage and trade balance.

Furthermore, the Rybczynski theorem explains that the increase in one of factor supplies (for example, capital) increases production of capital-intensive products but decreases production of products that use other factor supplies intensively (for example, labour). The theorem displays how changes in an endowment affect the outputs of the goods when full employment is sustained [11]. Using the data of 20 OECD countries in the period from 1970 to 1985, Harrigan [12] found a linear Rybczynski relationship among sectoral outputs and factor endowments across countries. There is evidence that the source of comparative advantage depends on relative factor supplies [13, 14]. If the central bank expands the monetary base by lowering policy rates, the cost of capital decreases and the supply and demand of capital expands. Furthermore, Rybczynski theorem predicts that the increase in the production of capital-intensive goods also will decrease other non-capital-intensive goods $[15,16]$ even though Bernstein \& Weinstein [17] found other conclusions contradicting it.

However, the Leontief's paradox revealed the contradiction: the U.S. (the most capital-abun- 
dant country) exported labour-intensive products and imported capital-intensive products [18]. The paradox diminishes if labour is categorized as skilled labour (human capital) and unskilled labour. The U.S. tends to export skilled labour-intensive products and import unskilled labour-intensive products. Based on this conclusion, in this study we can categorize the human capital-intensive products (industry that requires skilled labour in production) as capital-intensive products, same as technology-intensive products.

The other studies show that the lower price of input will increase all production. Using the US data for the period from 1979 to 2001, Akay and Dogan [15] found that the increase in labour supply rises output in all industries, however, the magnitude depends on the elasticity of each particular industry. In concordance to Akay and Dogan [15], Hanson and Slaughter [16], using the OLS method and 40 sectors in US period 1980-1990, revealed that there is a linear relationship between labour supply and the change of output in the US.

The research of Bergin and Corsetti [19] found the influence of interest rates on comparative advantage done. The authors used New Keynesian model to prove that monetary policy can increase comparative advantage of a firm. Bergin and Corsetti [19] explained that low interest rates will encourage new firms' entry since it will increase expected discounted profit by creating a new firm. They used the data of the US (home country) and the aggregate of 10 EURO countries (foreign countries) for the period from 1972 to 2004 and discovered that the monetary policy increases the competitiveness of firms, encourages investment, products differentiation, increases output and export. However, the evidence showed that the rise of competitiveness is more relevant for exported manufactured than for domestic manufacturing sector. The empirical findings of Bergin and Corsetti support the integrating between trade and macro models. In contrast, Ridhwan et al. [7] found that monetary policy influences output but insignificantly affects export.

\section{Methods and Data}

This paper uses data on exports and imports, three-digit Standard International Trade Classification (SITC) ${ }^{1}$ Revision 2, published by the United Nations Commodity Trade Statistics

\footnotetext{
${ }^{1}$ The Standard international trade classification, abbreviated as SITC, is a product classification of the United Nations (UN) used for external trade statistics (export and Import values and volumes of goods), allowing for international comparisons of commodities and manufactured goods (Eurostat-statistics explained at https://ec.europa.eu, 2019).
}

Database (UN-COMTRADE) for the period from 2001 to 2017. We focus on the group of products systemized by Empirical Trade Analysis (ETA). ETA identifies the following five products or industries: primary industries (83 products), natural resource-intensive industries (21 products), unskilled labour-intensive industries (26 products), technology-intensive industries (62 products), and human capital-intensive industries (43 products). The classification from ETA can be seen in Table 1. We used technology-intensive products and human capital-intensive products as capital-intensive products. However, unskilled labour-intensive products (UL) are used as a control group that is compared to classifications 4 and 5, Technology-intensive products (TI) and Human capital-intensive products (HC). We use Primary product $(\mathrm{P})$ and Natural-resource intensive products (NR) as benchmark to measure the influence of the ITF on comparative advantage and trade balance of TI and HC in Logit model. The procedure of comparing the groups is discussed later.

We employ Revealed Symmetric Comparative Advantage (RSCA) by Laursen [20] and Trade Balance Index by Lafay [21] to measure comparative advantage and trade balance. RSCA is formulated as follows:

$$
R S C A_{i j}=\frac{\left(R C A_{i j}-1\right)}{\left(R C A_{i j}+1\right)},
$$

where $-1 \leq R S C A_{i j} \leq 1 . R S C A_{i j}>0$ implies that a country $i$ has comparative advantage in a group of products $j$. However, $R S C A_{i j}<1$ means that a country $i$ has comparative disadvantage in a group of products $j$.

Furthermore, RSCA in equation (8) is formulated based on Revealed Comparative Advantage $(R C A)$ or Balassa index [22]. RCA index is formulated as follows:

$$
R C A_{i j}=\left(X_{i j} / X_{i n}\right)\left(X_{w j} / X_{w n}\right),
$$

where $R C A_{i j}$ represents revealed comparative advantage of a country $i$ for a group of products (SITC) $j$; and $X_{i j}$ denotes total exports of a country $i$ in a group of products (SITC) $j$. Subscript w refers to all countries and subscript $n$ refers to all groups of products (SITC).

The other considered indicator is Trade Balance Index (TBI) [21] that analyses whether a country has specialization in export (as net-exporter) or import (as net-importer) for a specific group of product (SITC). TBI $I_{i j}$ denotes trade balance index of a country $i$ for a group of products (SITC) $j ; x_{i j}$ and $m_{i j}$ represents exports and imports of a group of products $j$ by country $i$, respectively. TBI is formulated as: 
Table 1

Product classification

(1) Primary products $(P)$

001, 011, 012, 014, 022, 023, 024, 025, 034, 035, 036, 037, 041, 042, 043, 044, 045, 046, 047, 048, 054, 056, 057, 058, 061, 062, 071, 072, 073, 074, 075, 081, 091, 098, 111, 112, 121, 122, 211, 212, 222, 223, 232, 233, 244, 245, 246, 247, 248, 251, $261,263,264,265,266,267,268,269,271,273,274,277,278,281,282,286,287,288,289,291,292,322,323,333,334$, $335,341,351,411,423,424,431,941$

(2) Natural resource-intensive products $(N R)$

$524,611,612,613,633,634,635,661,662,663,667,671,681,682,683,684,685,686,687,688,689$

(3) Unskilled labour-intensive products (UL)

$651,652,653,654,655,656,657,658,659,664,665,666,793,812,821,831,842,843,844,845,846,847,848,851,894,895$

(4) Technology-intensive products (TI)

$511,512,513,514,515,516,522,523,541,562,272,582,583,584,585,591,592,598,711,712,713,714,716,718,721$,

$722,723,724,725,726,727,728,736,737,741,742,743,744,745,749,751,752,759,764,771,772,773,774,775,776$,

$778,792,871,872,873,874,881,882,883,884,893,951$

(5) Human capital-intensive products $(H C)$

$531,532,533,551,553,554,621,625,628,641,642,672,673,674,675,676,677,678,679,691,692,693,694,695,696$, $697,699,761,762,763,781,782,783,784,785,786,791,885,892,896,897,898,899$

(6) Others

$911,931,961,971,999$

Products codes are based on three-digit SITC Rev. 2.

Source: Widodo [23], also available at ETA; (http://www2.econ.uu.nl/users/marrewijk/eta/intensity.htm by Hinloopen and Marrewijk).

$$
T B I_{i j}=\frac{x_{i j}-m_{i j}}{x_{i j}+m_{i j}},
$$

where $-1 \leq T B I_{i j} \leq 1$. TBI $=-1$ means a country only imports, in contrast, the $T B I=1$ means a country only exports.

First method to assess the role of the ITF is "product mapping”. Widodo [23] uses the RSCA and TBI indexes to construct the "product mapping”. He categorizes products into four groups A, B, C and D as depicted in Figure 3. Widodo [23] explains that group A consists of products which have both comparative advantage and export specialization; Group B consists of products which have a comparative advantage but no export specialization; Group C consists of products which have export specialization but no comparative advantage, and Group D consists of products which have neither comparative advantages nor export specialization. The products in region A are categorized as potential products.

Furthermore, the second method to measure the influence of the ITF on comparative advantage and trade balance is Difference in Differences (DD) model. In the DD, the data comes from two groups of units of analysis that have similar characteristics. For example, group A that is impacted by policy (of participants) and group B that is not impacted by policy (control). In this study, we compare a group of products influenced by the ITF that includes capital-intensive products $(\mathrm{TH}=\mathrm{TI}+\mathrm{HC})$ and a control group that is not influenced $(U L)$.

In Figure 3 we assumed that the distance between the groups $\mathrm{B}$ and $\mathrm{A}$ at the time before the ITF or at $t_{0}$ is $\left(Y_{1}-Y_{0}\right)$, where $Y$ is $R S C A$ or TBI index. The distance $Y_{3}-Y_{2}$ at the next measurement at $t_{1}$ measures the increase of $Y$ without the ITF. Furthermore, the distance between $Y_{3}$ and $Y_{4}$ is impact of the ITF on $Y$. Khandker et. al. [24, p. 78] also state the advantage of the DD is relaxing the assumption of conditional selection only on observed characteristics. It also provides a tracta-

\begin{tabular}{|c|c|}
\hline $\begin{array}{c}\text { Group B: } \\
\text { Have Comparative Advantage } \\
\text { No Export Specialization (net-importer) } \\
(R S C A>0 \text { and } T B I<0)\end{array}$ & $\begin{array}{c}\text { Group A: } \\
\text { Have Comparative Advantage } \\
\text { Have Export Specialization (net-importer) } \\
(R S C A>0 \text { and } T B I>0)\end{array}$ \\
\hline $\begin{array}{c}\text { Group D: } \\
\text { No Comparative Advantage } \\
\text { No Export Specialization (net-importer) } \\
(R S C A<0 \text { and } T B I<0)\end{array}$ & $\begin{array}{c}\text { Group C: } \\
\text { No Comparative Advantage } \\
\text { Have Export Specialization (net-importer) } \\
(R S C A>0 \text { and } T B I<0)\end{array}$ \\
\hline
\end{tabular}

Source: Widodo [23].

Fig. 2. Product mapping 


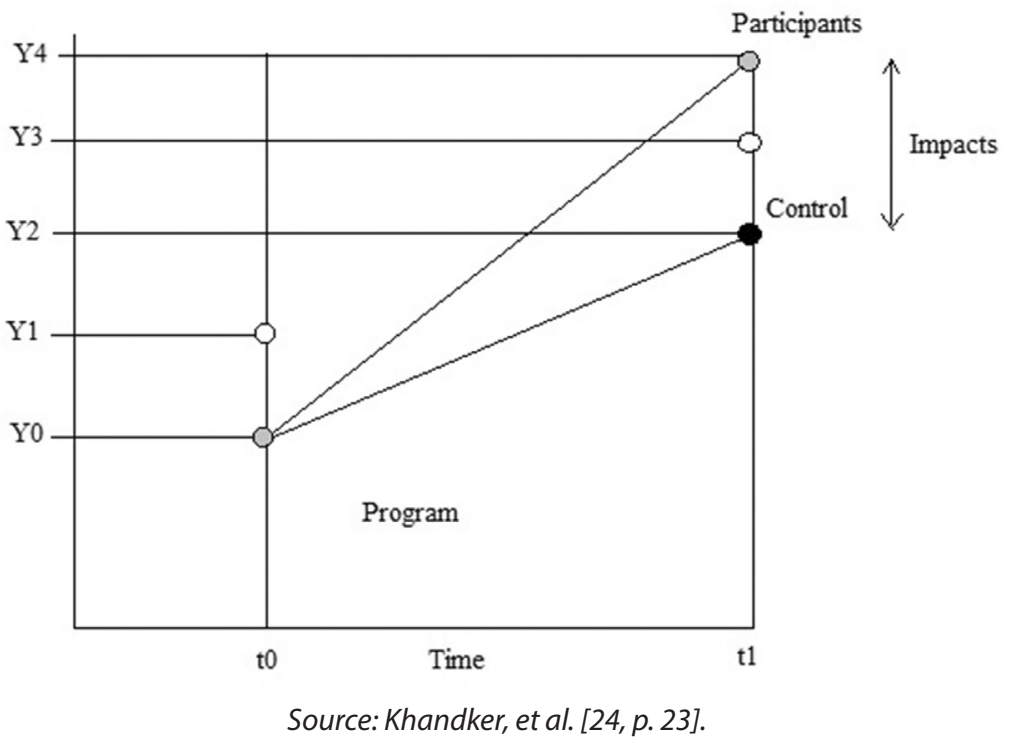

Fig. 3. Reason for the DD model

ble, intuitive way to account for selection on unobserved characteristics.

We employ Ordinary Least Square (OLS) to estimate the DD. In the model, 2000 is used as the time before the policy $\left(t_{0}\right)$ and 2014 is used as the time of the policy $\left(t_{1}\right)$. White heteroskedasticity-consistent standard errors and covariance are applied in the model; UL is used as control variable. The model for TI can be formulated as:

$$
\begin{aligned}
& R S C A_{i t}=\beta_{0}+\delta_{0} d 14_{i t}+\beta_{1} d t e c h_{i t}+\delta_{1} d 14_{i t} \text { dtech }_{i t}+e_{i t}, \\
& T B I_{i t}=\beta_{0}+\delta_{0} d 14_{i t}+\beta_{1} d t e c h_{i t}+ \\
&+\delta_{1} d 14_{i t} d t e c h_{i t}+e_{i t},
\end{aligned}
$$

where $d 14$ is a dummy variable for 2014 (period of policy) and dtech is dummy variable for TI. Furthermore, the DD for $\mathrm{HC}$ is estimated using the following equation:

$$
\begin{aligned}
& R S C A_{i t}=\beta_{0}+\delta_{0} d 14_{i t}+\beta_{1}{d \operatorname{dhum}_{i t}}+\delta_{1} d 14_{i t} \text { dhum }_{i t}+e_{i t}, \\
& T B I_{i t}=\beta_{0}+\delta_{0} d 14_{i t}+\beta_{1} d h u m_{i t}+ \\
&+\delta_{1} d 14_{i t}{d \text { hum }_{i t}+e_{i t},}
\end{aligned}
$$

where dhum is a dummy variable for HC. In the DD, coefficient $\delta_{1}$ is important because it measures the real impact of the ITF on RSCA and TBI (distance between $Y_{4}$ and $Y_{3}$ in Figure 3).

The third method is to measure the impact of the ITF on comparative advantage and trade balance is Logit model. This model will measure the influence of the ITF on probability of positive change of $R S C A\left(D R S C A_{i t}=R S C A_{i t}-R S C A_{i, t-1}\right)$ and $T B I\left(D T B I_{i t}=T B I_{i t}-T B I_{i, t-1}\right)$. We use dummy variables dumDRSCA and dumDTBI that are categorized 1 if $R S C A$ or $T B I$ rise and 0 if others.

In Logit model, the probability of RSCA or TBI increase can be formulated as

$$
P_{i t}=E\left(Y=1 \mid X_{i t}\right)=\frac{1}{1+e^{\beta_{0}+\beta_{1} X_{i t}}}
$$

or it can be re-written as:

$$
P_{i t}=\frac{1}{1+e^{z}}=\frac{e^{z}}{1+e^{z}},
$$

where $z_{i}=\beta_{0}+\beta_{1} X_{i t}$. If $P_{i t}$ is the probability of RSCA or TBI increase (PdumDRSCA or PdumDTBI) then probability of $R S C A$ or TBI not increasing is $\left(1-P_{i}\right)$. We can formulate the following equation as:

then

$$
1-P_{i t}=\frac{1}{1+e^{z}},
$$

$$
\frac{P_{i t}}{1-P_{i t}}=\frac{1+e^{z}}{1+e^{-z}}=e^{z}
$$

where $\frac{P_{i t}}{1-P_{i t}}$ is odds ratio or ratio of RSCA or TBI growth and non-growth. The ratio (16) can be stated in linear form as:

$$
L_{i t}=\ln \left(\frac{P_{i t}}{1-P_{i t}}\right)=z_{i}=\beta_{0}+\beta_{1} X_{i t},
$$

where $L_{i}$ is log of odds that is linear in $X$ and parameter. $L$ is Logit, so $L_{i}=\beta_{0}+\beta_{1} X_{i}$ is Logit model.

Furthermore, we formulate 2 Logit equations for each RSCA and TBI. The first equations are formed based on Taylor rule (equation 1 plus depreciation of Rupiah per US Dollar or Rp/USD). The equations can be stated as:

$$
\begin{gathered}
\text { dumRSCA } A_{i t}=a_{1} r_{i t}+a_{2} r_{i t} d^{d u m I T F} F_{i t}+a_{3} \pi m_{i t}+ \\
+a_{4} S \pi m_{i t}+a_{5} S Y_{i t}+a_{6} \Delta K_{i t}+u_{i t}
\end{gathered}
$$

and 


$$
\begin{gathered}
\operatorname{dumTBI}_{i t}=a_{1} r_{i t}+a_{2} r_{i t} d_{\text {umITF }}+a_{3} \pi m_{i t}+ \\
+a_{4} S \pi m_{i t}+a_{5} S Y_{i t}+a_{6} \Delta K_{i t}+u_{i t},
\end{gathered}
$$

where $r_{i t}$ is real interest rate $\left(i_{i t}-\left(\pi m_{i t} \times 12\right)\right), i_{i t}$ is nominal interest rate or official policy rate, $\pi m_{i t}$ is inflation month-to-month ( $\mathrm{mtm}), \mathrm{S} \pi m_{i t}$ is a gap between inflation $\mathrm{mtm}$ and expected inflation mtm (shock of inflation), $S Y_{\text {it }}$ is gap between actual GDP and potential GDP (shock of output). We use the Hodrick-Presscot filter (HP filter) to calculate expected inflation and Potential GDP. $\Delta K_{i t}$ is monthly depreciation rate of exchange rate (Rp/ USD). Finally, dumITF it is a dummy variable for the ITF, where 0 is before the ITF and 1 is during the ITF implementation (2005-2017). We use dumITF to find whether there is deferent effect of real interest rates on RSCA or TBI before and during the ITF.

Since we use yearly RSCA and TBI but monthly inflation, interest rates, and exchange rates, then we use the average monthly inflation, interest rates, and the average quarterly GDP in a year. We use the data from 2000 to 2017. We also use average monthly shock of inflation and average shock of output in a year.

The coefficient $a_{1}$ in (18) measures the influence of $r_{i t}$ on PdumDRSCA (PdumDTBI). Furthermore, $a_{1}$ $+a_{2}$ measures the influence of $r_{i t}$ on PdumDRSCA (PdumDTBI) in the period of the ITF implementation. If $a_{2}$ is positive and significant, then the ITF influences the comparative advantage (trade balance) of TH.

We also estimate the following 2 model, equations (20) and (21), to find the different effect of $r_{i t}$ on PdumDRSCA or PdumDTBI for different group of products before the ITF and during the ITF implementation. We use a dummy variable for capital-intensive product $(T H=T I+H C)$, dumTH, and a dummy variable for Unskilled-labour intensive products, dumUL. Furthermore, primary and natural-resource intensive products (PNR) are benchmark variables in Logit regression. The model can be formulated as:

$$
\begin{gathered}
\operatorname{dumRSCA}_{i t}=a_{1} r_{i t}+\beta_{1} r_{i t} d \mathrm{dumUL}_{i t}+ \\
+\beta_{2} r_{i t} \mathrm{dumTH}_{i t}+a_{2} r_{i t} \mathrm{dumITF}_{i t}+ \\
+\lambda_{1} r_{i t} \operatorname{dumITF}_{i t} \mathrm{dumUL}_{i t}+\lambda_{2} r_{i t} \mathrm{dumITF}_{i t} \mathrm{dumTH}_{i t}+ \\
+a_{3} \pi m_{i t}+a_{4} S \pi m_{i t}+a_{5} S Y_{i t}+a_{5} \Delta K_{i t}+u_{i t}
\end{gathered}
$$

and

$$
\begin{aligned}
& \operatorname{dumTBI}_{i t}=a_{1} r_{i t}+\beta_{1} r_{i t} d u m U L_{i t}+ \\
& +\beta_{2} r_{i t} d_{\text {dumTH }}+a_{2} r_{i t} d_{\text {dumITF }}+ \\
& +\lambda_{1} r_{i t} \text { dumITF }_{i t} \text { dumUL }_{i t}+\lambda_{2} r_{i t} \text { dumITF }_{i t} \text { dumTH }_{i t}+ \\
& +a_{3} \pi m_{i t}+a_{4} S \pi m_{i t}+a_{5} S Y_{i t}+a_{5} \Delta K_{i t}+u_{i t} .
\end{aligned}
$$

Coefficients a1 and a1+a2 measure the influence of $r_{i t}$ on PdumDRSCA (or PdumDTBI) for benchmark before and during the ITF. Coefficients $a_{1}+\beta_{1}$ and $a_{1}+\beta_{2}$ measure the influence of $r_{i t}$ on PdumDRSCA (or PdumDTBI) of UL and TH compared to benchmark before the ITF. Finally, coefficients $a_{1}+\beta_{1}+a_{2}+\lambda_{1}$ and $a_{1}+\beta_{2}+a_{2}+\lambda_{2}$ measure the influence of $r_{i t}$ on PdumDRSCA (or PdumDTBI) for UL and TH during the ITF implementation. Furthermore, if coefficients $\lambda_{1}$ and $\lambda_{2}$ are significant then the influence of $r_{i t}$ during the ITF implementation is higher than pre-ITF.

\section{Results and Discussion}

\section{Product Mapping}

Figure 4 shows products mapping for unskilled labour-intensive products (UL) in 2000, before the ITF, and in 2014, during the ITF. The number of potential products, the region $\mathrm{A}$ in the product mapping, is decreasing for UL.

The significant change exists in TBI where many products, that were previously located in the regions A and C in 2000, have positive net exports, moving to the regions $\mathrm{B}$ and $\mathrm{D}$. The number of potential products in region $\mathrm{A}$ is also reduced as they move to the other regions. The number of products in region $\mathrm{D}$, that have a comparative disadvantage and negative net exports, also increases in 2014.

Figure 5 shows product mapping for technology-intensive products (TI) in 2000, before the ITF, and in 2014, during the ITF implementation. The number of potential products in the region $\mathrm{A}$ in the product mapping decreased from 6 to 4 products. The significant change exists in TBI where many products that were previously located in the region C in 2000 (have a comparative disadvantage but positive net exports) moved to the region $\mathrm{D}$, as both comparative advantage and trade balance turned negative.

Figure 6 shows product mapping for human capital-intensive products (HC) in 2000 and 2014. The number of potential products in the region $\mathrm{A}$ in the product mapping also changed from 10 to 8 products. Furthermore, differing from UL and TI, the product in region $\mathrm{C}$ is still the same in both years.

Product mappings demonstrate that the situation in 2014 is worse than in 2000 for all group of products. The number of UL products leaving region A is bigger than in other groups. The HC demonstrated better results than other groups since only 2 products left region A and the number of products in region $C$ remained unchanged. Product mappings show that generally the situa- 

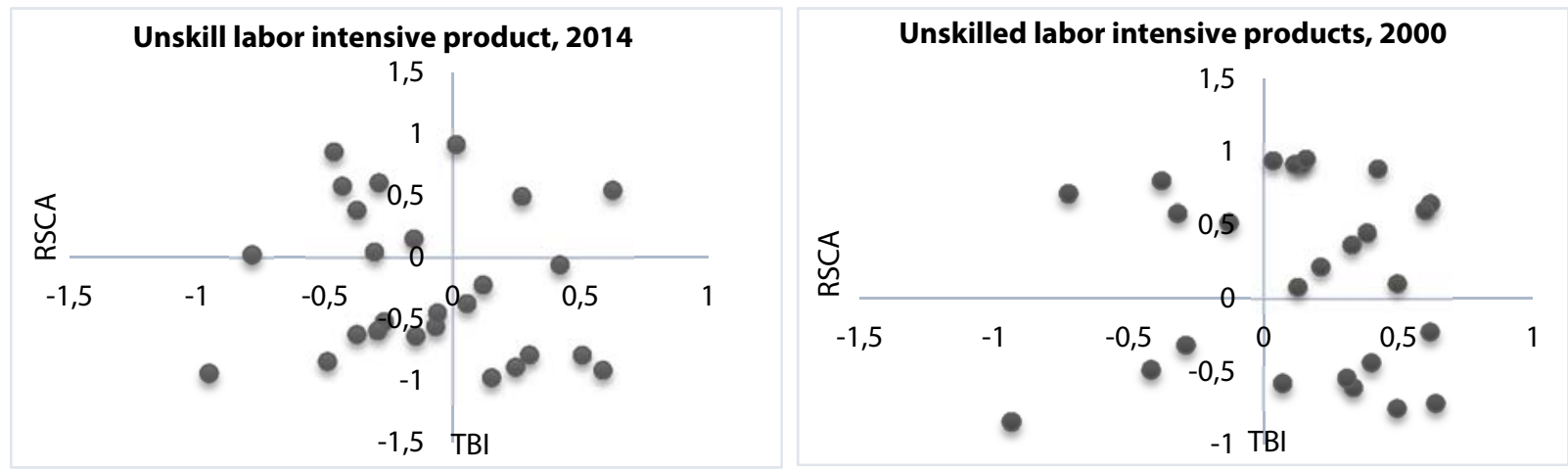

Fig. 4. Product mapping for unskilled labour-intensive products

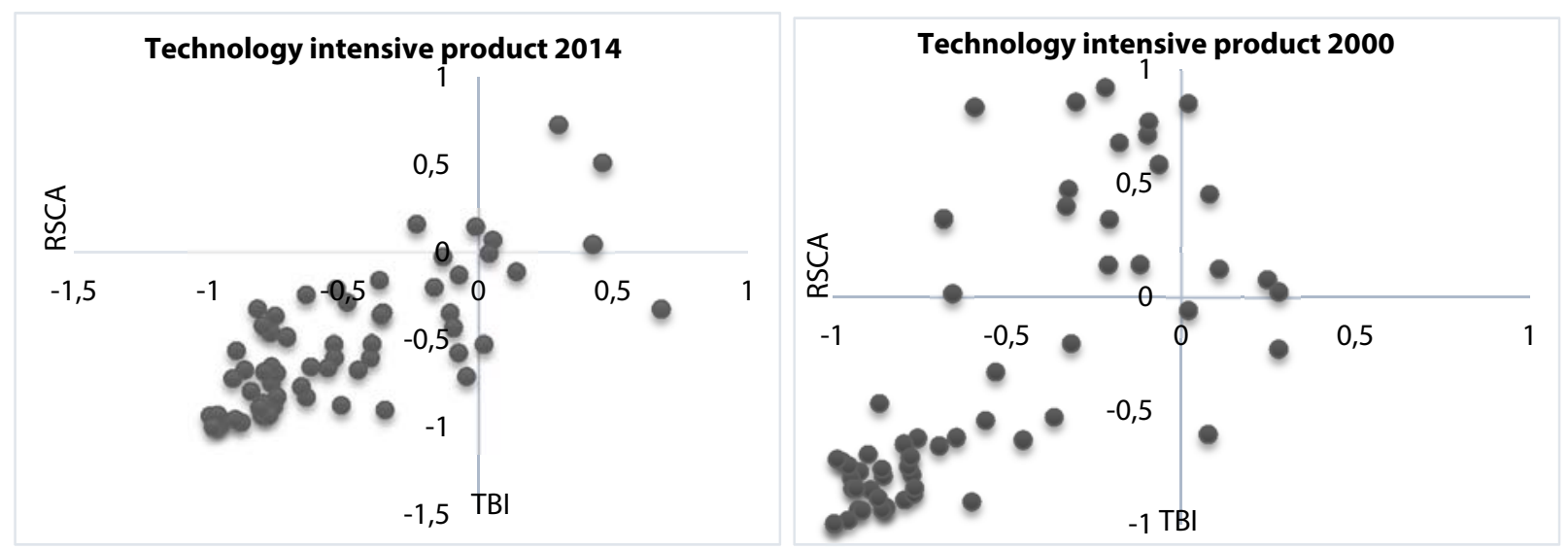

Fig. 5. Product mapping for technology-intensive products

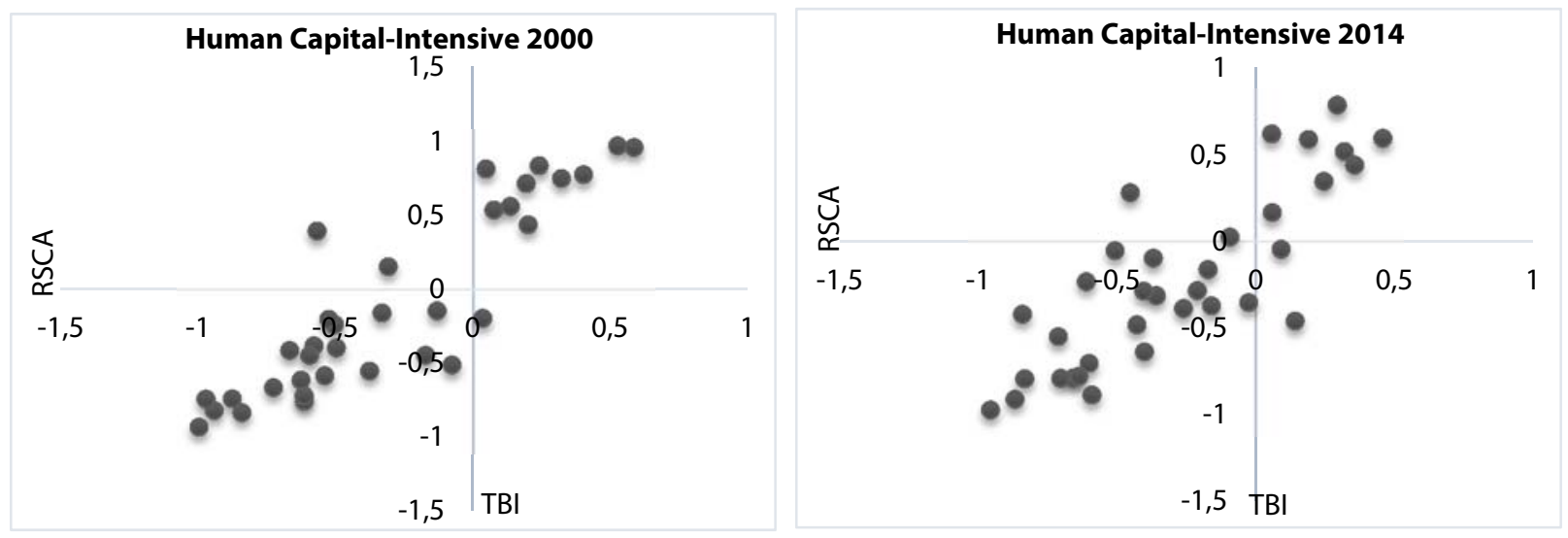

Fig. 6. Products mapping for human capital-intensive products

tion in 2000 is better than in 2014 for UL, HI, and TI. However, we realize that not only the ITF influences comparative advantage and trade balance but also lot of factor beyond it. Since it is difficult to exclude the effects of non-ITF factor in the common model, we use the DD to estimate the only ITF influence of capital-intensive products.

\section{Difference in Differences (DD) Estimation}

The DD estimation is applied on RSCA and TBI for TI and HC. The constant of equations $\beta 0$ shows the RSCA and TBI for UL in 2000. All of the coefficients are positive but not significantly different than zero. The negative sign of $\beta 1$ implies that in 2000 UL have better RSCA and TBI than TI and HC (Indonesia was not a capital-intensive country before the ITF). Coefficient $\beta 0$ and $\beta 1$ show that Indonesia generally did not have strong comparative advantage and positive trade balance both in UL and capital-intensive products (TH) in 2000. Furthermore, negative sign of coefficient d14 implies that the comparative advantage and trade balance for UL in 2014 are worse than in 2000 (the conclusion are the same as after product mappings).

Furthermore, the DD coefficient $\delta 1$ for TI explains that the ITF has a significantly positive influence on comparative advantage that is higher 
Table 2

The DD estimation for RSCA and TBI

\begin{tabular}{|c|c|c|c|c|}
\hline \multirow{2}{*}{ Coefficient } & \multicolumn{2}{|c|}{ Technology-intensive products (TI) } & \multicolumn{2}{|c|}{ Human capital-intensive product (HC) } \\
\cline { 2 - 5 } & $\boldsymbol{R S C A}$ & $\boldsymbol{T B I}$ & $\boldsymbol{R}$ SCA & TBI \\
\hline$\beta_{0}$ & 0.125281 & 0.159385 & 0.125281 & 0.159385 \\
\hline$\delta_{0}$ & $-0.207951^{* * *}$ & $-0.372801^{* *}$ & $-0.20795^{* *}$ & $-0.37280^{* *}$ \\
\hline$\beta_{1}$ & $-0.653383^{*}$ & $-0.496843^{* * *}$ & $-0.42812^{*}$ & -0.260986 \\
\hline$\delta_{1}$ & $0.245470^{* * *}$ & 0.195711 & 0.227461 & 0.258091 \\
\hline
\end{tabular}

Significant at the level of significance ${ }^{*} 1 \%,{ }^{* *} 5 \%,{ }^{* * *} 10 \%$.

Table 3

Logit estimation of equation 18 and 19

\begin{tabular}{|c|c|c|c|c|}
\hline \multirow{2}{*}{ Coefficient } & \multicolumn{2}{|c|}{ dumRSCA (18) } & \multicolumn{2}{|c|}{ dumTBI (19) } \\
\hline & Coef. & $z$-stat. & Coef. & $z$-stat. \\
\hline$a_{1}$ & $0.020550^{* *}$ & 2.213458 & $0.029029^{* * *}$ & 3.141840 \\
\hline$a_{2}$ & $-0.051793^{* * *}$ & -3.609116 & $-0.032497^{*}$ & -2.268229 \\
\hline$a_{3}$ & $-0.105323^{*}$ & -1.778241 & $-0.336919^{* * *}$ & -5.663638 \\
\hline$a_{4}$ & -0.224070 & -0.978222 & 0.321783 & 1.399992 \\
\hline$a_{5}$ & $9.16 \mathrm{E}-07$ & 0.197246 & $2.68 \mathrm{E}-06$ & 0.573656 \\
\hline$a_{6}$ & $0.000128^{* * *}$ & 3.450637 & $4.24 \mathrm{E}-05$ & 1.143791 \\
\hline Mean dependent var & \multicolumn{2}{|c|}{0.494861} & \multicolumn{2}{|c|}{0.458376} \\
\hline S.E. of regression & \multicolumn{2}{|c|}{0.498682} & \multicolumn{2}{|c|}{0.497756} \\
\hline Sum squared resid & \multicolumn{2}{|c|}{966.3832} & \multicolumn{2}{|c|}{962.8006} \\
\hline Log likelihood & \multicolumn{2}{|c|}{-2684.533} & \multicolumn{2}{|c|}{-2677.366} \\
\hline
\end{tabular}

Significant at the level of significance ${ }^{*} 1 \%,{ }^{* *} 5 \%,{ }^{* * *} 10 \%$.

than UL in 2000. However, the coefficients do not show the significantly different influence of the ITF on comparative advantage of $\mathrm{HC}$ and trade balance of TI and HC than UL in 2000. The result tells us the ITF only increases comparative advantage of TI.

\section{Logit Estimation}

We employ Logit model to find the influence of real interest rates $\left(r_{i t}\right)$ on the probability of the positive changes of $R S C A$ and TBI (PdumDRSCA and $P d u m D T B I$ ) of technology intensive products (TI) and human capital-intensive products (HC). The study uses yearly data for the period from 2001 to 2017.

The positive and significant coefficient of $r_{i t}, a_{1}$ in Table 3 shows that PdumDRSCA and PdumDTBI increase when $r_{i t}$ increases in pre-ITF. The coefficient $a_{1}$ does not support the prediction of theory. However, during the ITF implementation, the $r_{\text {it }}$ negatively influences $R S C A$ and $T B I$. The negative sign of $a_{2}$ implies the influence of $r_{i t}$ during the ITF implementation is lower than pre-ITF and negative value of $a_{1}+a_{2}$ implies there are negative relationship between $r_{i t}$ and PdumDRSCA as well as between $r_{i t}$ and PdumDTBI during the ITF implementation. The coefficients during the ITF implementation support the prediction of the HOS theory. Furthermore, the estimation of (18) and (19) also show the negative relationship between inflation and PdumDRSCA (PdumDTBI) as well as positive relationship among output and exchange rate to PdumDRSCA (PdumDTBI).

Equations (20) and (21) also measure the influence of the ITF on PdumDRSCA (PdumDTBI) with primary and natural resource-intensive products $(P$ and $N R$ ) that are used as benchmark. Table 4 shows the result of Logit estimations of (20) and (21) and Table 5 shows Wald test aimed at measuring combination coefficient in Table 4.

The positive and significant coefficient $r_{i t}, a_{1}$, in Table 5 shows that PdumDRSCA (PdumDTBI) of benchmark increases when $r_{i t}$ increases in preITF. The coefficient $a_{1}+\beta_{1}$ shows $r_{i t}$ does not significantly influences PdumDRSCA (PdumDTBI) of UL in pre-ITF. Furthermore, the measurement of $a_{1}+\beta_{2}$ implies there is positive relation between rit and PdumDRSCA (PdumDTBI) of TH, contradicting with the theory.

However, the influence of $r_{i t}$ on PdumDRSCA and PdumDTBI during the ITF implementation generally confirms the prediction of the theory. The signs of coefficients $a_{1}+a_{2}+\beta_{1}+\lambda_{1}$, and $a_{1}+a_{2}+\beta_{2}+\lambda_{2}$ for RSCA in Table 5 for UL and TH are negatively significant, implying negative relationship between $r_{i t}$ and PdumDRSCA of UL and TH. However, only PdumDTBI of UL is negatively significant and is influenced by $r_{i t}$. 
Logit estimation of equation (20) and (21)

\begin{tabular}{|c|c|c|c|c|}
\hline \multirow{2}{*}{$\begin{array}{c}\text { Dependent } \\
\text { variable_(20) }\end{array}$} & \multicolumn{2}{|c|}{ dumTBI (21) } & \multirow[b]{2}{*}{ Coef. } & \multirow[b]{2}{*}{$z$-stat. } \\
\hline & Coef. & $z$-stat. & & \\
\hline$a_{1}$ & $0.0278^{*}$ & 1.926 & $0.0332^{* * *}$ & 2.327 \\
\hline$\beta_{1}$ & $-0.0663^{* *}$ & -2.425 & -0.0335 & -1.236 \\
\hline$\beta_{2}$ & 0.0051 & 0.266 & 0.0013 & 0.069 \\
\hline$a_{2}$ & -0.0355 & -1.619 & -0.0234 & -1.070 \\
\hline$\lambda_{1}$ & -0.0041 & -0.096 & -0.0452 & -1.060 \\
\hline$\lambda_{2}$ & -0.0376 & -1.331 & -0.009 & -0.330 \\
\hline$a_{3}$ & $-0.1067^{*}$ & -1.798 & $-0.3358^{* * *}$ & -5.636 \\
\hline$a_{4}$ & -0.2082 & -0.904 & 0.3371 & 1.459 \\
\hline$a_{5}$ & $1.43 \mathrm{E}-06$ & 0.308 & $3.04 \mathrm{E}-06$ & 0.649 \\
\hline$a_{6}$ & $0.0001^{* *}$ & 3.489 & $4.45 \mathrm{E}-05$ & 1.196 \\
\hline $\begin{array}{c}\text { Mean } \\
\text { dependent var }\end{array}$ & \multicolumn{2}{|c|}{0.494861} & \multicolumn{2}{|c|}{0.458376} \\
\hline $\begin{array}{c}\text { S.E. of } \\
\text { regression }\end{array}$ & \multicolumn{2}{|c|}{0.498084} & \multicolumn{2}{|c|}{0.497505} \\
\hline $\begin{array}{l}\text { Sum squared } \\
\text { resid }\end{array}$ & \multicolumn{2}{|c|}{963.0744} & \multicolumn{2}{|c|}{960.8402} \\
\hline Log likelihood & \multicolumn{2}{|c|}{-2677.917} & \multicolumn{2}{|c|}{-2673.385} \\
\hline
\end{tabular}

Significant at the level of significance ${ }^{*} 1 \%,{ }^{* *} 5 \%,{ }^{* * *} 10 \%$.

Finally, the values of $a_{2}, a_{2}+\lambda_{1}$, and $a_{2}+\lambda_{2}$ in table 5 show the change of influence of $r_{i t}$ on PdumRSCA (PdumDTBI) caused by the ITF implementation. The ITF changes the behavioural relations between $r_{i t}$ and PdumDRSCA of PNR and TH. The ITF also changes the behavioural relation between rit and PdumTBI of UL and TH. Table 5 supports the theory that during the ITF, rit influences RSCA and TBI negatively and capital-intensive product benefit more than other group of products.

\section{Conclusion}

The ITF policy in Indonesia aimed to reduce inflation using nominal interest rates as operational targets. The ITF has been introduced in 2001 and formally executed in 2005, gradually reducing inflation by lowering the policy nominal interest rate. The decline of it was also accompanied by a decrease in interest rates on loans for investment, as well as real interest rates that should favour capital-intensive industry. From the perspective of international trade, lower interest rates should increase comparative advantage of the capital-intensive industry that will impact trade balance. This study uses real interest rate as the ITF variable since in real value it reflects inflation as a target of monetary policy.

ETA groups products based on the factors that are used intensively in production. We examined the influence of the ITF on comparative advantage and trade balance of capital-intensive products (technology-intensive and human capital-intensive products) using such methods as Product Mappings, Difference in Differences, and Logit model. We used unskilled labour-intensive products as a control group in the DD model, since it is assumed they are not significantly influenced by the real interest rate. As a control group, it is also assumed to be affected by factors excluding the ITF, same as capital intensive groups.

Based on product mappings, we cannot conclude that the situation is better in 2014 (during the ITF implementation) than in 2000. The fact may be caused by the impact of the global crisis of 2009-2010 [25, 26, p. 41], meaning that the industry has not fully recovered in 2014. Even though the model successfully explores the comparative advantage and trade balance together and analysse the competitiveness of products, we cannot measure the influence statistically and precisely. Thus, we used the DD and Logit model to

Table 5

Effect of the ITF on Each Group of Product

\begin{tabular}{|c|c|c|c|c|c|}
\hline \multirow{2}{*}{\multicolumn{2}{|c|}{ (1) Before the ITF }} & \multicolumn{2}{|c|}{ dumDRSCA } & \multicolumn{2}{|c|}{ dumDTBI } \\
\hline & & \multirow{2}{*}{$\begin{array}{c}\text { Coef. } \\
0.02777^{*}\end{array}$} & \multirow{2}{*}{$\begin{array}{c}\text { F-stat. } \\
3.708\end{array}$} & \multirow{2}{*}{$\begin{array}{c}\text { Coef. } \\
0.0332^{* *}\end{array}$} & \multirow{2}{*}{$\begin{array}{c}\text { F-stat. } \\
5.415\end{array}$} \\
\hline$P$ and $N R$ & $a_{1}$ & & & & \\
\hline$U L$ & $a_{1}+\beta_{1}$ & -0.0385 & 2.649 & -0.0003 & 0.000 \\
\hline$T H$ & $a_{1}+\beta_{2}$ & $0.0328^{* * *}$ & 6.180 & $.0345^{* * *}$ & 7.003 \\
\hline \multicolumn{2}{|c|}{ (2) During the ITF } & & & & \\
\hline$P$ and $N R$ & $a_{1}+a_{2}$ & -0.0078 & 0.200 & 0.0098 & 0.317 \\
\hline$U L$ & $a_{1}+a_{2}+\beta_{1}+\lambda_{1}$ & $-0.0785^{* * *}$ & 6.882 & $-0.0689^{* * *}$ & 5.340 \\
\hline TH & $a_{1}+a_{2}+\beta_{2}+\lambda_{2}$ & $-0.0403^{* * *}$ & 6.207 & 0.0019 & 0.013 \\
\hline \multicolumn{2}{|c|}{$(2)-(1)$} & & & & \\
\hline$P$ and $N R$ & $a_{2}$ & $-0.0663^{* * *}$ & 5.878 & -0.0335 & 1.528 \\
\hline (a) $U L$ & $a_{2}+\lambda_{1}$ & -0.0396 & 1.126 & $-0.0686^{*}$ & 3.389 \\
\hline (b) $\mathrm{TH}$ & $a_{2}+\lambda_{2}$ & $-0.0731^{* * *}$ & 13.464 & $-0.0327^{*}$ & 2.724 \\
\hline
\end{tabular}

Significant at ${ }^{*} \alpha=10 \%,{ }^{* *} \alpha=5 \%,{ }^{* * *} \alpha=1 \%$. 
cover the weakness of the first model and complete each other.

The DD explains the decline was not caused by the ITF since it really measures the effect of the ITF by comparing the variables between two points of time. The DD coefficient that measures real effect of the ITF shows that the ITS influences comparative advantage of technology-intensive and human capital-intensive products way more than it influences unskilled labour-intensive products. However, the influence of the ITF on trade balance of technology- and human capital-intensive products relatively is not different comparing with the influence on unskilled labour-intensive products.

The result of the Logit model shows that, during the ITF implementation, the influence of real interest rates on the comparative advantage of the capital-intensive and unskilled labour-intensive products supports the prediction of the HOS model. However, real interest rate's influence on trade balance supports the prediction of HOS only for unskilled labour-intensive products. On the other hand, real interest rate's influence on trade balance of capital-intensive products is getting closer to HOS during the ITF implementation.

Furthermore, the results of the Logit model demonstrate that the ITF changes the relations between interest rate and trade balance for capital intensive and unskilled labour-intensive products. However, the ITF only significantly change the relations between real interest rate and comparative advantage for capital-intensive products.

The study confirms the predictions of the HOS model satating there are negative relationship between interest rates and comparative advantage during the ITF implementation. Capital-intensive products gets benefit from the ITF implementation more than unskilled labour-intensive products. The research concludes that the ITF encourages the increase in comparative advantage and trade balance of products and supports the longterm growth policy (MP3EI).

\section{References}

1. Taylor, J. B. (1993). Discretion versus policy rules in practice. Carnegie-Rochester Conference Series on Public Policy, 39, 195-214. North-Holland. DOI: 10.1016/0167-2231(93)90009-L

2. Woodford, M. (2001). The Taylor rule and optimal monetary policy. American Economic Review, 91(2), $232-237$. DOI: $10.1257 /$ aer.91.2.232

3. Utama, C. Miryam B. L. W. \& Lim, C. (2017). The role of interest rates and provincial monetary aggregate in maintaining inflation in Indonesia. Buletin Ekonomi Moneter dan Perbankan, 19(3), 267-286. DOI: 10.21098/bemp.v19i3.666.

4. MacDonald, R. \& Nagayasu, J. (2000). The long-run relationship between real exchange rates and real interest rate differentials: A panel study. IMF staff papers, 47(1), 116-128. Retrieved from: https://www.imf.org/en/ Publications/WP/Issues/2016/12/30/The-Long-Run-Relationship-Between-Real-Exchange-Rates-and-Real-Interest-RateDifferentials-A-2912 (Date of access: 11.03.2018).

5. Why the manufacturing sector still matters for growth and development in Indonesia. Policy Note. (2012). World Bank.

6. Bowen, H. P., Hollander, A. \& Viaene, J.-M. (2001) Applied International Trade Analysis. United States of America: The University of Michigan Press, 143.

7. Ridhwan, M. M., De Groot, H. L., Nijkamp, P. \& Rietveld, P. (2010). The impact of monetary policy on economic activity - evidence from a meta-analysis. Tinbergen Institute Discussion Paper No. 3. Retrieved from: https://papers.tinbergen. nl/10043.pdf (Date of access: 03.08.2016).

8. Barth III, M. J. \& Ramey, V. A. (2001). The cost channel of monetary transmission. NBER Macroeconomics Annual $2001,16,199-256$

9. Jorgenson, D. W. (1963). Capital theory and investment behavior. American Economic Review, 53(2), $247-259$. Retrieved from: https://www.nber.org/chapters/c1235.pdf (Date of access: 02.03.2018).

10. Grossman, G. M. \& Helpman, E. (1990). Comparative Advantage and Long-Run Growth. The American Economic Review, 80(4), 796-815.

11. Rybczynski, T. M. (1955). Factor Endowment and Relative Commodity Prices. Economica, 22(88), 336-341. DOI: $10.2307 / 2551188$.

12. Harrigan, J. (1995). Factor endowments and the international location of production: econometric evidence for the OECD, 1970-1985. Journal of International Economics, 39(1-2), 123-141. DOI: 10.1016/0022-1996(94)01361-U

13. Harrigan, J. \& Zakrajsek, E. (2000). Factor supplies and specialization in the world economy. NBER Working Paper No. 7848. DOI: 10.3386/w7848.

14. Reeve, T. A. (2006). Factor endowments and industrial structure. Review of International Economics, 14(1), 30-53. DOI: 10.1111/j.1467-9396.2006.00559.x

15. Akay, G. H. \& Dogan, C. (2013). The effect of labo r supply changes on output: empirical evidence from US industries. Journal of Productivity Analysis, 39(2), 123-130. DOI: 10.1007/s11123-012-0290-2.

16. Hanson, G. H. \& Slaughter, M. J. (1999). The Rybczynnski theorem, factor-price equalization, and immigration: evidence from U.S States. NBER Working Paper No. 7074. 
17. Bernstein, J. R. \& Weinstein, D. R. (2002). Do endowments predict the location of production? Evidence from national and international data. Journal of International Economics, 56, 55-76. DOI: 10.3386/w6815.

18. Leontief, W. (1954). Domestic Production and Foreign Trade - The American Capital Position Reexamined. Economia Internazionale, 7(1), 9-45.

19. Bergin, P. R. \& Corsetti, G. (2015). Beyond competitive devaluation: the monetary dimension of comparative advantage. Cambridge-INET Working Paper No. 16. DOI: 10.17863/CAM.5785.

20. Laursen, K. (1998). Revealed comparative advantage and the alternatives as measures of international specialization. Working paper Danish Research Unit for Industrial Dynamics (DRUID), No. 98-30. Retrieved from: https://wp.druid.dk/ wp/19980030.pdf (Date of access: 03.08.2016).

21. Lafay, G. (1992). The measurement of revealed comparative advantages. In: M. G. Dagenais, P. A. Muet (Eds.), International Trade Modeling (pp. 209-234). London: Chapman \& Hill.

22. Balassa, B. (1965). Trade liberalization and "revealed" comparative advantage. The Manchester School of Economics and Social Studies, 33(2), 99-123. DOI: 10.1111/j.1467-9957.1965.tb00050.x.

23. Widodo, T. (2008). Dynamic changes in comparative advantage: Japan "flying geese" model and its implications for China. Journal of Chinese Economic and Foreign Trade Studies, 1(3), 200-213. DOI: 10.1108/17544400810912365.

24. Khandker, S. R., Koolwal, G. B. \& Samad, H. A. (2010). Handbook on Impact Evaluation Quantitative Methods and Practices. Washington DC: The International Bank for Reconstruction and Development, 239.

25. Shelburne, R. C. (2010). The Global Financial Crisis and Its Impact on Trade: The world and The European Emerging Economies. Discussion Paper. United Nations Economic Commission for Europe. Retrieved from: https://www.unece.org/ fileadmin/DAM/oes/disc_papers/ECE_DP_2010-2.pdf (Date of access: 11.03.2018)

26. Damuri, Y. R., Setiati, I., Atje, R. \& Santosoç, B. (2015). European Report on Development 2015. Financing and other means of implementation in the post-2015 context, Indonesia Country Illustration. Retrieved from: https://ec.europa.eu/europeaid/sites/devco/files/erd5-country-illustration-indonesia-2015_en.pdf (Date of access: 03.07.2018).

\section{Authors}

Chandra Utama - Doctor of Economics, Lecturer, Economics Department; Researcher, Center of Economics Studies (CES), Universitas Katolik Parahyangan-Indonesia (94, Ciumbuleuit St., Hegarmanah, Kec. Cidadap, Kota Bandung, Jawa Barat, 40141, Indonesia; e-mail: chandradst@unpar.ac.id)

Ruth Meilianna - Researcher, Population Research Center, Lembaga Ilmu Pengetahuan Indonesia (Indonesian Institute of Sciences) (10, Jend. Gatot Subroto St., Jakarta Selatan, 12710, Indonesia). 